\title{
Effects of nutrient discharge by river water and waste water on the nitrogen dynamics in the archipelago of Göteborg, Sweden
}

\author{
Johanne-Sophie Selmer ${ }^{1}$, Lars Rydberg ${ }^{2}$ \\ ${ }^{1}$ Department of General and Marine Microbiology, University of Göteborg, Carl Skottsbergs Gata 22, \\ S-413 19 Göteborg, Sweden \\ ${ }^{2}$ Department of Oceanography, University of Göteborg, Box 4038, S-400 40 Göteborg, Sweden
}

\begin{abstract}
Nutrient dynamics within the strongly stratified River Göta älv estuary were investigated during 1988 to 1990 by measuring salinity and nutrient concentrations as well as uptake, mineralization and denitrification processes (using ${ }^{15} \mathrm{~N}$ technique and the acetylene inhibition method). The river supply was the most dominating contribution to the inorganic nitrogen budget with an addition of nearly $6000 \mathrm{mmol} \mathrm{s}^{-1}$, mainly in the form of nitrate. Further addition to the estuary from the waste water supply and deep water supply amounted to ca 3800 and $2900 \mathrm{mmol} \mathrm{s}^{-1}$, respectively. Ammonium was the main component of the waste water supply. Phosphate supply was dominated by the deep water while the contribution of river and waste water was low. Generally, the estuary is phosphate-limited. Indirect calculations, based on salinity and nutrient measurements, indicated considerable sinks for nitrate and ammonium within the surface water of the estuary. Excluding the winter period with low primary production, the sink for nitrate was $2600 \mathrm{mmol} \mathrm{s} \mathrm{s}^{-1}$ and for ammonium $3200 \mathrm{mmol} \mathrm{s}^{-1}$, corresponding to a total sink of $250 \mathrm{nmol}^{-1} \mathrm{~h}^{-1}$. Measured uptake rates, on the other hand, were much lower. The nitrate uptake was 10 to $20 \mathrm{nmol} \mathrm{l}^{-1} \mathrm{~h}^{-1}$ and the ammonium uptake averaged $60 \mathrm{nmol} \mathrm{l}^{-1}$ $\mathrm{h}^{-1}$ Neither phytoplankton biomass, chlorophyll a nor oxygen concentrations indicated high primary production which could explain the nitrogen sink. This apparent discrepancy is discussed.
\end{abstract}

\section{INTRODUCTION}

Many Swedish coastal waters today suffer from frequent eutrophication effects, such as algal blooms and oxygen deficit. During the past decade, it has become evident that such occurrences are caused by increased nutrient supply from different anthropogenic sources: agriculture, fossil fuel burning and waste water discharge (Rosenberg et al. 1990, Rydberg et al. 1990). During the 1960's, however, many inland waters in Sweden were already eutrophicated, with phosphorus being the limiting nutrient. The 1970's found most waste water treatment plants in Sweden reducing the phosphorus load by up to $90 \%$ by using chemical precipitation. These measures had apparent positive effects on the water quality of inland waters. No effects were noted in the coastal waters, however, except for the archipelago of Stockholm (Brattberg 1986).

It was not until the mid-1980's that it was more generally accepted that algal growth in coastal waters was limited by nitrogen rather than phosporus (Graneli et al. 1986, 1990, Rydberg 1986). In view of these findings, nitrogen removal from waste water has now come under debate. Waste water nitrogen supply to coastal waters is, however, small compared to other nitrogen sources. In the Baltic, $30 \%$ of the nitrogen load is due to atmospheric deposits and $60 \%$ is river induced, while only about $10 \%$ originates from waste water (Larsson et al. 1985). The situation is similar on the west coast of Sweden; waste water discharge comprises less than $10 \%$ of the total load to the Kattegat (Rydberg et al. 1990). Thus, nitrogen removal in waste water should only have a marginal or, at the least, mainly local effect on the growth of marine phytoplankton.

In Göteborg on the Swedish west coast, the sources of nitrogen loading are of special interest to those concerned with nitrogen reduction in waste water. 


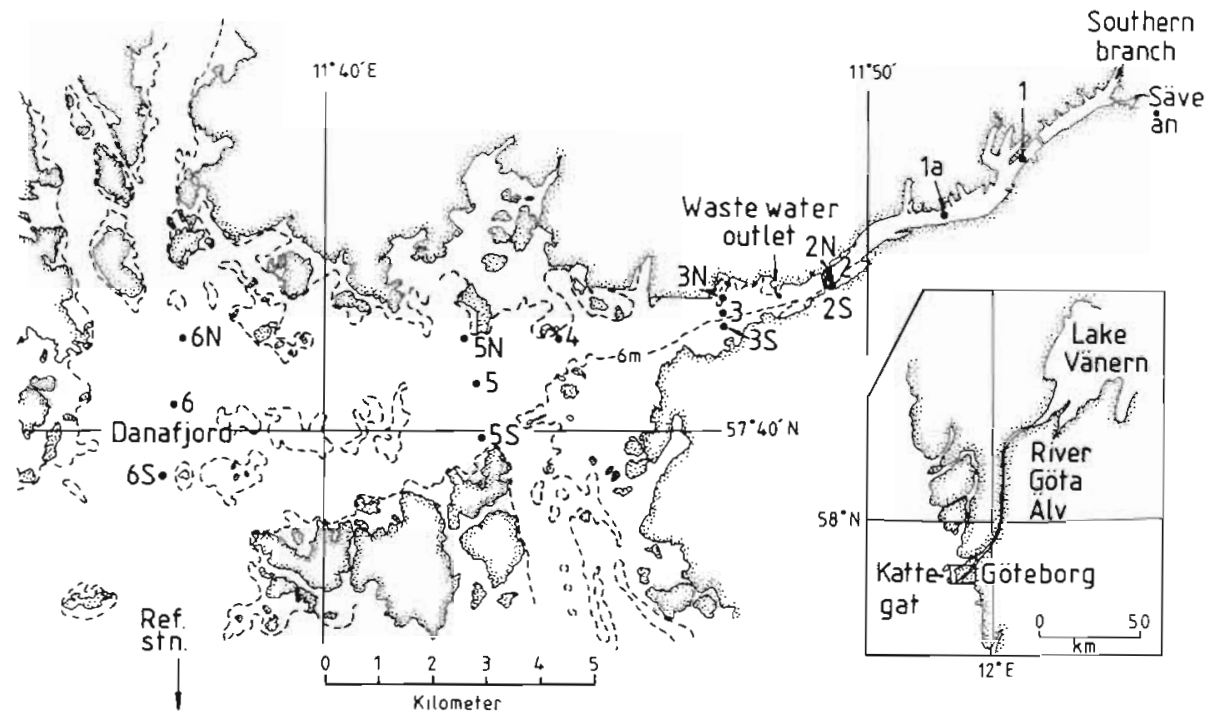

Fig. 1. Sampling stations along the southern branch of River Göta älv and its estuary near Göteborg, Sweden. The reference station is positioned $5 \mathrm{~km}$ further south
Göteborg is situated at the estuary of the River Göta älv, the largest river in Sweden (Fig. 1). According to monthly observations on nutrient concentrations in the river, perforuled by the Sivedish Environmental Protection Agency, the yearly transport of total nitrogen varies between 10000 and 20000 tons, of which $25 \%$ passes through the city in the southern branch of the river. Organic nitrogen amounts to ca $35 \%$ of the total nitrogen. The Göteborg waste water treatment plant (Ryaverket, GRYAAB) is situated in the middle section of the estuary with waste water adding another 2000 tons of total nitrogen $\mathrm{yr}^{-1}$. While the river nitrogen flux consists mainly of nitrate, the dominating constituent in waste water is ammonium (Söderström 1986). Justifiably, the inhabitants of Göteborg raised the question as to whether it is worth while spending $\$ 25$ to 30 million per year in waste water treatment, which can, at best, reduce the nitrogen load by only 1000 tons $\mathrm{yr}^{-1}$.

The main aim of our study was to obtain some detailed insight into the fate of nutrients within the estuary. From earlier studies in the River Nissan, further south on the west coast of Sweden, we found that the river nitrogen concentrations decreased rapidly outside the river mouth. This rapid decrease could not be explained by mixing with seawater alone, and was therefore interpreted as an effect of intensive plankton nutrient uptake (Rydberg 1986). This conclusion was confirmed by direct measurements of nitrogen uptake (E. Sahlsten pers. comm.). Generally, processes such as nutrient uptake by phytoplankton, mineralization. sedimentation, nitrification and denitrification are all likely to affect the nutrient distribution within the estuary and to determine how far out to sea increased nutrient concentrations and other effects of the nutrient supply can be recorded. We thus approached the problem from 2 different viewpoints: directly, by way of rate determinations of uptake and mineralization (using ${ }^{15} \mathrm{~N}$ technique) and denitrification (using the acetylene inhibition method): and indirectly, by way of frequent salinity, nutrient and current measurements from which we made indirect calculations of various nutrient sources and sinks within the estuary.

In earlier estuarine studies of the River Göta älv, it was concluded that a large part of the nitrogen supply was denitrified in the estuary (Söderström 1986, unpubl.). This conclusion, however, was based exclusively on observations of nutrient concentrations. No direct measurements of nutrient uptake or denitrification were made.

Investigations of other coastal waters in Sweden receiving treated waste water are few, but measurements have been performed for many years outside waste water treatment plants in the Stockholm archipelago on the Baltic coast. Here, phosphorus reduction resulted in not only fewer cyanobacterial blooms, but also in an increased transport of nitrogen further out in the archipelago (Brattberg 1986). Similar effects were seen in Himmerfjärden, south of Stockholm (Elmgren 1988), where experiments with phosphorus and nitrogen reduction were carried out in the local waste water treatment plant. Increased phosphorus load resulted in cyanobacterial blooms in the inner area of Himmerfjärden due to nitrogen limitation, while conversely, high nitrogen load resulted in increasing primary production.

\section{MATERIALS AND METHODS}

Sampling and hydrography. Ship-based measurements were undertaken from July 1988 to March 1990 
on RV 'Falsterbo' and RV 'Navicula' on a total of $10 \mathrm{oc}$ casions. Additional expeditions were also made to study a few selected parameters. Sampling dates are shown in Table 1. The station net (Fig. 1) was chosen in order to cover the area from (primarily) pure river water, to (primarily) Kattegat surface water inside the outer archipelago. In addition, a reference station for unaffected Kattegat water was chosen in the southern archipelago. During 1988 sampling was made at the inner stations from Stn 1 to Stn 4. In 1989 the station net was extended to include a further 6 stations (Stns 5 , $5 \mathrm{~N}, 5 \mathrm{~S}, 6,6 \mathrm{~N} \& 6 \mathrm{~S}$ ) in 2 cross-sections further out in the estuary. Stn 1a was introduced as a special current meter station.

Normally the expeditions conducted water sampling for determination of temperature, salinity, oxygen, nitrate, nitrite, ammonium, phosphate and phytoplankton. Based on a detailed salinity profile (see below), 2 sampling depths were chosen: one in the homogeneous surface water (usually 0.5 or $1 \mathrm{~m}$ ), and one in the homogeneous deep water beneath the halocline. All results were correlated to the salinity, which was used as an independent variable throughout this study. Current measurements were made with a drift-cross. Water sampling for studies of nitrogen uptake, mineralization and denitrification, including determinations of particulate organic carbon, nitrogen and phosphorus, was made on a few occasions. Nitrogen uptake and mineralization studies were made on surface water, and denitrification studies were made on both surface and deep water. Table 1 summarizes the observed parameters during the various expeditions.

Water samples were taken with either 6 or $30 \mathrm{l}$ Niskin bottles. In situ salinity and temperature profiles were measured with a field salinometer (Mark 2, Woodmill Electronics), the salinity of each water sample being also determined with a Guildline laboratory salinometer. The salinity is given in 'practical salinity units' (psu).

Analytical methods. All filtering was performed with ashed $25 \mathrm{~mm}$ Whatman GF/F glass fibre filters (ashed at $450^{\circ} \mathrm{C}$ for $2 \mathrm{~h}$ ). For all incubations and chemical analyses only acid-washed material was used $(2 \% \mathrm{HCl})$.

Nitrate, nitrite, ammonium and phosphate samples were filtered and flash-frozen on board in a mixture of dry ice and ethanol. Immediately before analysis the nutrient samples were thawed in a microwave oven. Ammonium was analyzed according to the phenolhypochlorite method (Solorzano 1969), nitrite and nitrate according to Armstrong et al. (1967), and phosphate according to Koroleff (1976). All methods were modified for the Technicon Autoanalyzer II.

Samples for determination of particulate organic carbon, nitrogen and phosphorus were stored in dark polyethylene bottles, and filtered the same day in the laboratory. The filters were stored in an evacuated desiccator until analysis. Particulate organic carbon and nitrogen were analyzed on a Carlo Erba Elemental Analyzer Model 1106. Particulate organic phosphorus was determined according to Valderrama (1981). Samples for chlorophyll a ( $\mathrm{chl} \mathrm{a}$ ) determinations were taken on some incubation occasions, extracted according to Strickland \& Parsons (1968) and analyzed on a Turner Filter Fluorometer Model 111. Oxygen was titrated by the Winkler method according to Carlberg (1972).

Nitrogen transformations. Water samples for nitrogen uptake and mineralization studies were transported to the laboratory in 60 l polyethylene bottles. The experimental work was carried out the day after sampling and incubations performed in either 2.6 or 41 polycarbonate bottles at in situ temperature and under fluorescent light $\left(115 \mu \mathrm{mol}^{-1} \mathrm{~m}^{-2} \mathrm{~s}^{-1}\right)$ over 5 to $6 \mathrm{~h}$.

Uptake of nitrate and ammonium were determined

Table 1. Dates for the different expeditions and parameters analyzed. For the 2 expeditions in May 1989, the connotation May I and May II will be used in the text. PC: particulate organic carbon; PN: particulate organic nitrogen; PP: particulate organic phosphorus

\begin{tabular}{|c|c|c|c|c|c|c|c|c|c|c|}
\hline & \multicolumn{2}{|c|}{1988} & \multirow[b]{2}{*}{$14 \mathrm{Apr}$} & \multirow[b]{2}{*}{8 May $^{\mathrm{C}}$} & \multicolumn{2}{|r|}{1989} & \multirow[b]{2}{*}{24 Aug } & \multirow[b]{2}{*}{$27 \mathrm{Sep}^{d}$} & \multirow[b]{2}{*}{2 Nov } & \multirow{2}{*}{$\begin{array}{c}1990 \\
7 \mathrm{Mar}\end{array}$} \\
\hline & $25 \mathrm{Jul}^{\mathrm{a}}$ & $17 \mathrm{Oct}^{\mathrm{b}}$ & & & 16 May & 19 Jun & & & & \\
\hline Nutrients & $\mathrm{x}$ & $\mathrm{x}$ & $\mathrm{x}$ & $x$ & $x$ & $x$ & $\mathrm{x}$ & $\mathrm{x}$ & $\mathrm{x}$ & $x$ \\
\hline Salinity & $\mathrm{x}$ & $\mathrm{x}$ & $\mathrm{x}$ & $\mathrm{x}$ & $\mathrm{x}$ & $\mathrm{x}$ & $\mathrm{x}$ & $\mathrm{x}$ & $\mathrm{x}$ & $\mathrm{x}$ \\
\hline Current measurements & $\mathrm{x}$ & $\mathrm{x}$ & $\mathrm{x}$ & $\mathrm{x}$ & $\mathrm{x}$ & $\mathrm{x}$ & $\mathrm{x}$ & $\mathrm{x}$ & $\mathrm{x}$ & $\mathrm{x}$ \\
\hline$P C, P N, P P$ & $\mathrm{x}$ & $\mathrm{x}$ & & $\mathrm{x}$ & & & & $\mathrm{x}$ & & \\
\hline Chlorophyll a & & & & $\mathrm{x}$ & & & & $\mathrm{x}$ & & \\
\hline Oxygen & & & & & $\mathrm{x}$ & $\mathrm{x}$ & $\mathrm{x}$ & & $\mathrm{x}$ & $\mathrm{x}$ \\
\hline Plankton & $\mathrm{x}$ & $\mathrm{x}$ & $\mathrm{x}$ & $\mathrm{x}$ & & $\mathrm{x}$ & $\mathrm{x}$ & $\mathrm{x}$ & $\mathrm{x}$ & $\mathrm{x}$ \\
\hline Nutrient uptake & $\mathrm{x}$ & $\mathrm{x}$ & & $\mathrm{x}$ & & & & $\mathrm{x}$ & & \\
\hline Mineralization & $\mathrm{x}$ & & & & & & & & & \\
\hline \multicolumn{9}{|c|}{ Denitrification $x$} & & \\
\hline Corresponding samplins & dates at & the refer & station: c & $28 \mathrm{Jul} 1$ & $988 ;{ }^{b} 20$ & Oct 198 & ${ }^{c} 11 \mathrm{~N}$ & 1989 & $25 \mathrm{Sep}$ & \\
\hline
\end{tabular}


by adding $98 \%{ }^{15} \mathrm{~N}-\mathrm{NO}_{3}{ }^{-}$and $98 \%{ }^{15} \mathrm{~N}-\mathrm{NH}_{4}{ }^{+}$respectively to separate incubation bottles. Ambient nutrient concentrations were measured prior to additions, which were devised to obtain concentrations of 0.1 and $5.0 \mu \mathrm{mol}^{15} \mathrm{~N} \mathrm{I}^{-1}$. Incubation was terminated by filtering 3 parallel replicates of $\leq 500 \mathrm{ml}$ from each incubation bottle. The filters were dried and stored in an evacuated desiccator for further analysis. Nitrogen in the samples was converted to $\mathrm{N}_{2}$ by Dumas combustion (Fiedler \& Proksch 1975 ) and the atom \% ${ }^{15} \mathrm{~N}$ was determined with emission spectrometry (Statron NOI-5 ${ }^{15} \mathrm{~N}$-Analyzer) according to Kristiansen \& Paasche (1982). Uptake rates were calculated according to Dugdale \& Wilkersson (1986).

Mineralization was determined according to Selmer \& Sörensson (1986) and Selmer (1988a), using the ${ }^{15} \mathrm{~N}$ isotope dilution method with subsequent extraction of indophenol. Ammonium additions were the same as for uptake studies, and diom \% " ${ }^{1} \mathrm{~N}$ was determined as described above. Mineralization rates were calculated according to the Blackburn-Caperon model (Blackburn 1979, Caperon et al. 1979).

Denitrification was detcrmincd by using the acetylene inhibition method (Sørensen 1979). Water samples were collected in $100 \mathrm{ml}$ serum bottles, and $9 \mathrm{ml}$ acetylene was subsequently added. One set of samples was terminated immediately by adding $0.5 \mathrm{ml} \mathrm{HgCl}_{2}$, thus giving the $\mathrm{N}_{2} \mathrm{O}$ concentration at the start of the experiment. The other samples were incubated during 24, 48 and $72 \mathrm{~h}$ at in situ temperature in fluorescent light for surface water samples or in the dark for deep

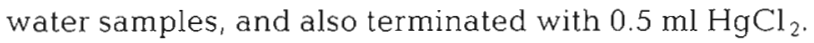
Concentrations of $\mathrm{N}_{2} \mathrm{O}$ were measured on a Packard gas chromatograph Model 428, with Porapak $N$ column.

\section{RESULTS}

\section{Hydrography and nutrients}

Hydrographical and hydrochemical raw data have been reported in a separate publication (Selmer \& Rydberg 1992). These raw data were used to calculate stationwise average values of salinity, nitrate, ammonium and phosphate based on the 6 expeditions carried out during 1989 (cf. Table 1). The results are shown in Table 2. The corresponding distributions of salinity and nutrients within the estuary are shown in Fig. 2a to d. The mean salinity distribution was drawn from mean stationwise salinity profiles taken from the field salinometer data. Corresponding nutrient profiles were interpolated ( 2 water samples taken at each station which related nutrient concentration to salinity) by assuming a linear relationship between nutrient concontration and salinity.

The mean cross-stream surface water salinity, based on data from 1989 (see above), is shown in Fig. 3. The coriolis force has an obvious effect downstream of Stn 4 where the estuary widens, implying a tendency for the waste water, of which the outlet is situated on the north side of the river, to retain its concentrated form far out into the estuary. Due to restricted mixing and weak lateral spreading of the waste water plume, the highest ammonium concentrations appear first at Stn 4 (see Fig. 2c), although Stn 3 is also situated downstream of the waste water outlet. Fig. 2a indicates an extremely strong stratification with a $2 \mathrm{~m}$ deep surface layer reaching from the innermost stations out through the entire estuary. Due to a high and relatively constant fresh water discharge, regulated at Lake Vänern (see below), the hydrographic conditions upstream of

Table 2. Mean values $(\bar{x})$ and standard deviations (o) of salinity (psu), nitrate, ammonium and phosphate (all in $\mu$ mol $1^{-1}$ ) based on observations during 1989

\begin{tabular}{|c|c|c|c|c|c|c|c|c|c|}
\hline & \multirow[t]{2}{*}{ Station } & \multicolumn{2}{|c|}{ Salinity } & \multicolumn{2}{|c|}{ Nitrate } & \multicolumn{2}{|c|}{ Ammonium } & \multicolumn{2}{|c|}{ Phosphate } \\
\hline & & $\bar{x}$ & $\sigma$ & $\bar{x}$ & $\sigma$ & $\bar{x}$ & $\sigma$ & $\bar{x}$ & $\sigma$ \\
\hline Surface & 1 & 0.85 & 0.5 & 35.35 & 2.8 & 1.68 & 0.8 & 0.05 & 0.0 \\
\hline \multirow[t]{6}{*}{ water } & $1 a$ & 2.25 & 1.0 & 33.44 & 3.6 & 2.32 & 1.0 & 0.13 & 0.1 \\
\hline & 2 & 5.30 & 3.2 & 29.16 & 4.8 & 2.90 & 1.2 & 0.19 & 0.1 \\
\hline & 3 & 9.30 & 3.6 & 22.49 & 6.8 & 9.03 & 2.8 & 0.25 & - \\
\hline & 4 & 11.20 & 2.0 & 19.20 & 4.7 & 14,42 & 7.3 & 0.24 & 0.1 \\
\hline & 5 & 14.71 & 1.8 & 12.92 & 4.1 & 6.95 & 4. 1 & 0.21 & 0.1 \\
\hline & 6 & 19.35 & 3.2 & 4.49 & 3.2 & 1.86 & 1.6 & 0.16 & 0.1 \\
\hline \multirow[t]{7}{*}{ Deep water } & 1 & 13.00 & 6.0 & 16.97 & 9.8 & 4.97 & 2.5 & 0.45 & 0.2 \\
\hline & $1 \mathrm{a}$ & 20.85 & 4.4 & 5.80 & 3.1 & 3.94 & 0.5 & 0.53 & 0.3 \\
\hline & 2 & 21.34 & 4.1 & 5.46 & 3.8 & 3.15 & 0.5 & 0.46 & 0.3 \\
\hline & 3 & 21.74 & 4.5 & 4.63 & 3.0 & 3.02 & 0.9 & 0.41 & 0.3 \\
\hline & 4 & 22.77 & 5.0 & 3.13 & 2.8 & 2.14 & 0.7 & 0.37 & 0.3 \\
\hline & 5 & 22.98 & 5.1 & 2.83 & 3.2 & 2.01 & 1.5 & 0.36 & 0.3 \\
\hline & 6 & 23.53 & 5.3 & 1.49 & 1.8 & 1.09 & 0.6 & 0.31 & 0.3 \\
\hline
\end{tabular}



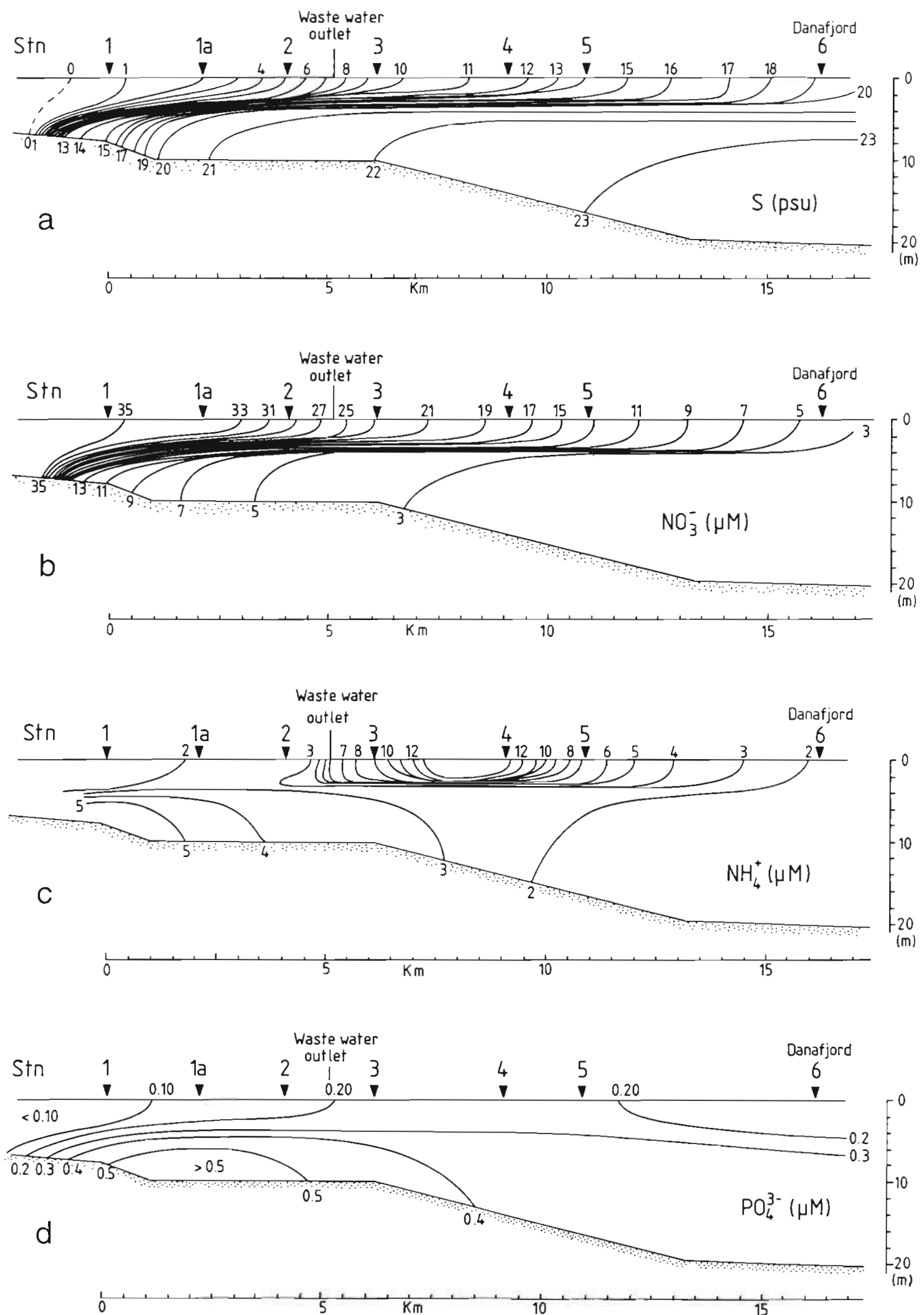

Fig. 2. Mean values of salinity (psu) and nutrient concentrations $\left(\mu \mathrm{mol} \mathrm{l}^{-1}\right)$ in the estuary based on 6 observations during 1989 (a) Salinity; (b) nitrate; (c) ammonium; and (d) phosphate 


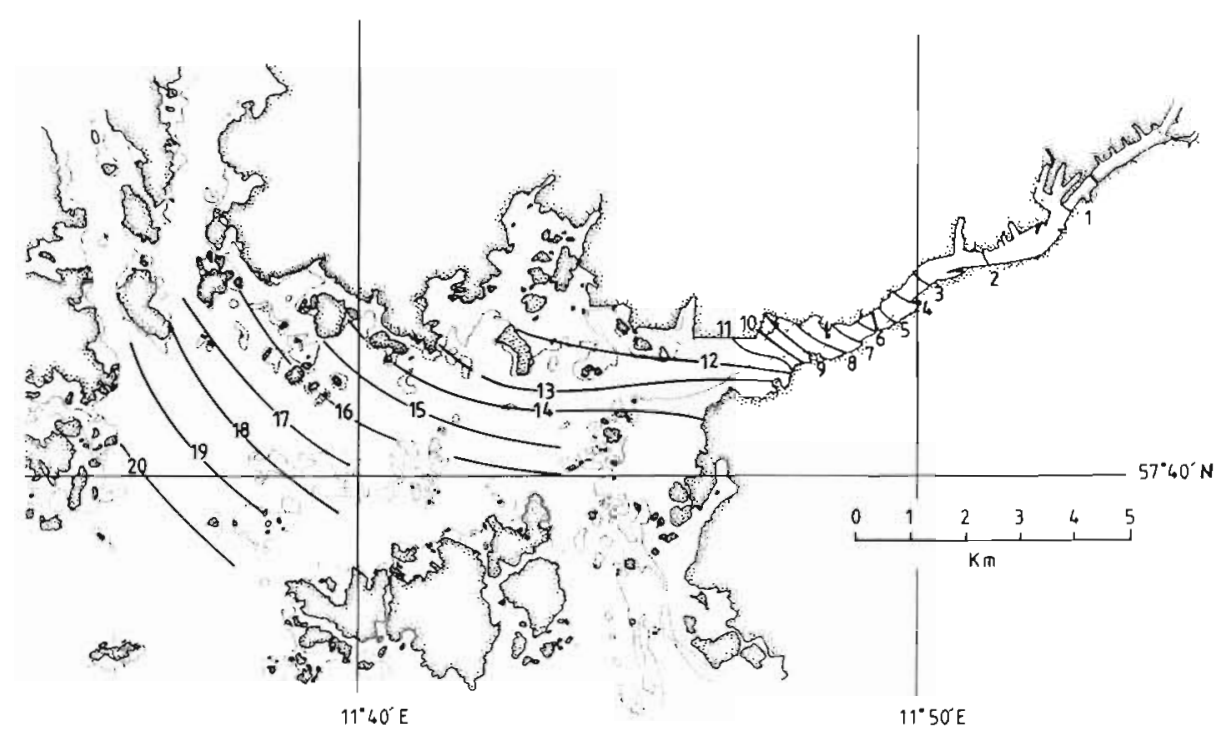

Fig. 3. Mean values of salinity (psu) in surface water based on 6 observations during 1989
Stn 3 are very stable, with standard deviations being remarkably small (Table 2). There is, however, a linear increase in salinity outwards in the surface water while the salinity in the deep water is nearly constant This indicates that the vertical mixing is dominated by upward entrainment, while downward entrainment is weak or negligible. Downstream of Stn 4 the estuary widens and wind stress rather than shear probably dominates the mixing, making the conditions therefore more unstable. The deep water originates from Kattegat surface water which has a salinity varying between 18 and 34 psu, and therefore the standard deviations in the deep water become greater than in the surface water (Table 2).

The nitrate distribution, shown in Fig. 2b, is similar in shape, but opposite in concentration to that of salinity. However, nitrogen transformations influence the picture considerably. A salinity-nitrate diagram based on the mean values from 1989 (Table 2) is shown in Fig. 4. The levels of the surface water nitrate concentrations on the outer stations are far below the mixing line between surface water and inflowing deep water, indicating that the nitrate distribution is influenced by a net nitrate sink. In the distribution of ammonium as shown in Fig. 2c, the dominating feature is the strongly increased concentrations due to the waste water outlet. There is also an increase in concentrations upstream within the deep water, indicating net mineralization in deep water and sediments. Phosphate concentrations are, as can be seen from Fig. 2d, extremely low within the fresh water, reflecting the phosphorus deficit in Lake Vänern. A net phosphorus mineralization is indicated in the deep water and sediments in the upper region of the estuary, but phosphate increase due to the waste water outlet is low.

A large supply of dissolved inorganic nitrogen (DIN) but a very low dissolved inorganic phosphorus (DIP) supply is reflected in the atomic ratios DIN:DIP. Mean ratios within the surface water, based on all measurements from 1988 to 1990 , are shown in Fig. 5. The fresh water ratio amounts to 800 . At Stns 5 and 6 the ratio is 105 and 35, respectively. Thus, compared to the Redfield ratio (of 16; Redfield et al. 1963), there is an extreme surplus of inorganic nitrogen in the estuary. Neither deep water import nor waste water supply changes these circumstances.

\section{River discharge}

The river discharge is measured continuously by the local Electricity Board at a power plant downstream of Lake Vänern. However, due to the division of the river $20 \mathrm{~km}$ from Göteborg (Fig. 1), it is impossible to obtain an exact flow estimate for the southern branch passing through the city. By means of a sluice in the northern branch, the Electricity Board regulates the flow in the

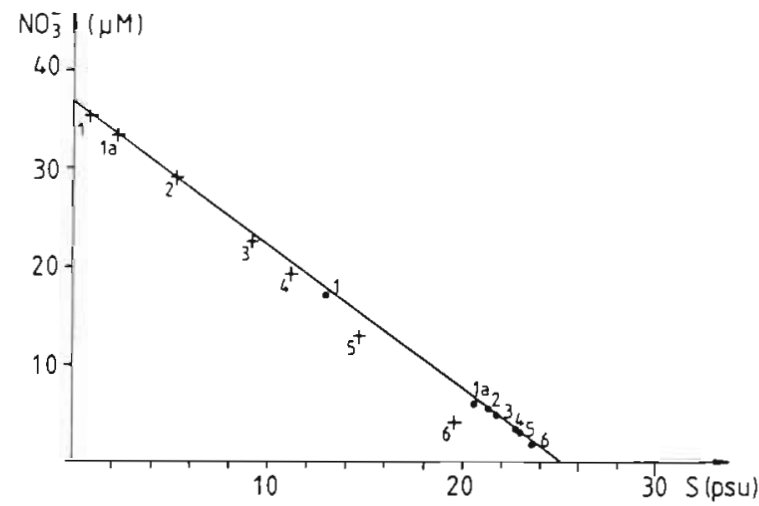

Fig. 4. Nitrate-salinity diagram based on 6 observations during 1989. (+) surface water, $(\bullet)$ deep water 


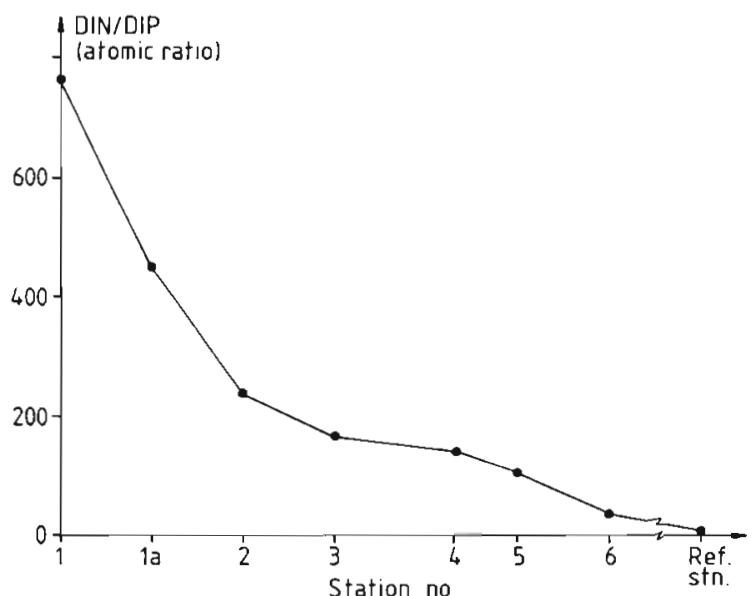

Fig. 5. Mean values of the atomic ratio between inorganic nitrogen and inorganic phosphorus (DIN/DIP) in the estuary and at the reference station, based on all observations (surface water)

southern branch to a value which fluctuates at around $150 \mathrm{~m}^{3} \mathrm{~s}^{-1}$. An estimate was obtained from the Electricity Board for each measuring period. This is shown, together with the discharge from the River Säveån which enters the estuary just upstream of Stn 1, in Table 3.

In order to test the above mentioned estimate, driftcross velocity measurements were made at Stn 1a. The measured surface water velocities were then multiplied by the corresponding surface water cross-section area to give the flow at this cross-section. Since the surface water salinity at Stn 1a deviates somewhat from zero, the resulting flow also exceeds the fresh water discharge. Eqs. 1a, b (conservation equations for volume and salt, see below) were used to calculate the corresponding supply of pure fresh water (Table 3). A comparison shows that the differences between the drift-cross measurements and the estimates were reasonably small (see 'Discussion'). In the forthcoming calculations, the fresh water supply $\left(Q_{\mathrm{f}}\right)$ will be taken as the arithmetric mean value between the 2 estimates.

\section{River and waste water nutrient supply}

Transport of nitrate, ammonium and phosphate in the southern branch were calculated separately for each expedition, by multiplying the fresh water discharge $\left(Q_{\mathrm{f}}\right)$ by the corresponding fresh water concentration $\left(C_{\mathrm{f}}\right)$ which was determined from measurements at Stn 1 . As the salinity was not exactly zero at Stn 1, a correction to fresh water concentration was made by using Eqs. 1a \& b (see below). $C_{f}$, and the corresponding transport of nitrate, ammonium and phosphate for each expedition during 1989, are shown in Table 4.

Supplies of nitrate, ammonium and phosphate from the waste water plant were determined in a similar way as the river transport. The flow of waste water, $Q_{w}$. varies on both shorter and longer time scales with a yearly mean value of ca $4 \mathrm{~m}^{3} \mathrm{~s}^{-1}$. Like the river discharge, $Q_{w}$ can be regulated within certain limits. During heavy rainfall the waste water flow is so large that 'uncontrolled' overflow may occur. There was. however, no overflow during our measurements. For the transport calculations, we used a mean value for the waste water volume flux, based on hourly measurements during a period of $24 \mathrm{~h}$ before sampling. The corresponding concentrations of ammonium, nitrate and phosphate, $C_{w}$ in the outgoing waste water were taken from measurements made by the waste water plant laboratory. $C_{w}$ is shown in Table 4.

Results from calculations of nutrient supply to the estuary shown in Table 4 indicate that the dominating nitrate source is the river transport, while waste water dominates the ammonium supply. The phosphate supply is small due to very low concentrations within the river water and an effective (95\%) phosphorus reduction in the waste water plant. However, the supply of

Table 3. Fresh water supply to the estuary and calculated flow at $\operatorname{Stn} 1 \mathrm{a}\left(\mathrm{m}^{3} \mathrm{~s}^{-1}\right)$, and wind direction and velocity $\left(\mathrm{m} \mathrm{s}^{-1}\right)$ during 1989 . Values for the southern branch of the river from the Electricity Board are daily averages. The variations during the day are marginal. Data for Säveån are based on monthly averages, while the drift-cross measurements were performed during the expedition. Since the salinity at $\operatorname{Stn} 1$ a deviates from zero, a conversion to the fresh water discharge was done by means of the mass (volume) and salt balance equations (Eqs. 1a, b in text). $Q_{f}$, the arithmetic mean (see text), is the value used in our calculations

\begin{tabular}{|c|c|c|c|c|c|c|c|}
\hline \multirow{2}{*}{$\begin{array}{l}\text { Date } \\
14 \mathrm{Apr}\end{array}$} & \multirow{2}{*}{$\begin{array}{c}\begin{array}{c}\text { Göta älv } \\
\text { (southern branch) }\end{array} \\
160\end{array}$} & \multirow{2}{*}{$\begin{array}{c}\text { River Säveån } \\
30\end{array}$} & \multirow{2}{*}{$\begin{array}{c}\text { Total discharge } \\
190\end{array}$} & \multirow{2}{*}{$\begin{array}{c}\text { Flow at } \operatorname{Stn} 1 \mathrm{a}^{\mathrm{d}} \\
150\end{array}$} & \multirow{2}{*}{$\begin{array}{c}Q_{1} \\
170\end{array}$} & \multicolumn{2}{|c|}{ Wind } \\
\hline & & & & & & $E$ & 5 \\
\hline 8 May & 160 & 20 & 180 & 162 & 171 & WNW & $8-12$ \\
\hline $16 \mathrm{May}$ & 170 & 15 & 185 & 116 & 150 & SSW & $6-10$ \\
\hline 19 Jun & 190 & 7 & 197 & 139 & 168 & $N$ & $4-6$ \\
\hline 27 Sep & 154 & 4 & 158 & - & 134 & $E$ & 3 \\
\hline 2 Nov & 152 & 8 & 160 & 151 & 156 & SE & 8 \\
\hline
\end{tabular}


Table 4. Nitrate, ammonium and phosphate concentrations, $C_{1}\left(\mu m o l l^{-1}\right)$, in the fresh water of River Göta alv and in the outgoing waste water; flow of waste water $\left(\mathrm{m}^{3} \mathrm{~s}^{-1}\right)$; and transport of nitrate, ammonium and phosphate $\left(\mathrm{g} \mathrm{s}^{-1}\right)$ via these sources. Mean transport of nitrate in the southern branch of Gota alv corresponds to 2567 ton $\mathrm{yr}^{-1}$, and transport of ammonium from the waste water treatment plant to 1660 ton $\mathrm{Yr}^{-1}$ Data on nutrients in the outgoing waste water are from the control program of GRYAAB (nitrogen), and the discharge control program of GRYAAB (phosphorus)

\begin{tabular}{|c|c|c|c|c|c|c|c|}
\hline \multirow[t]{2}{*}{ Date } & \multirow{2}{*}{$\begin{array}{l}\text { Water flow, } \\
Q_{\mathrm{f}} \text { or } Q_{\mathrm{w}}{ }^{\mathrm{a}}\end{array}$} & \multicolumn{3}{|c|}{ Concentration, $C_{1}$ or $C_{w}^{b}$} & \multicolumn{3}{|c|}{ Transport } \\
\hline & & $\mathrm{NO}_{3}^{-}$ & $\mathrm{NH}_{4}^{+}$ & $\mathrm{PO}_{4}{ }^{3-}$ & $\mathrm{NO}_{3}^{-}$ & $\mathrm{NH}_{4}^{+}$ & $\mathrm{PO}_{4}{ }^{3-}$ \\
\hline \multicolumn{8}{|c|}{ Göta älv } \\
\hline $14 \mathrm{Apr}$ & 170 & 40.1 & 2.4 & 0.03 & 95.4 & 5.4 & 0.16 \\
\hline 8 May & 171 & 37.8 & 0.7 & 0.00 & 90.5 & 1.7 & 0.00 \\
\hline 16 May & 150 & 36.6 & 1.1 & 0.02 & 76.9 & 2.3 & 0.09 \\
\hline 19 Jun & 168 & 33.1 & 1.0 & 0.02 & 77.9 & 2.4 & 0.11 \\
\hline 27 Sep & 134 & 34.0 & 2.2 & 0.04 & 63.8 & 4.1 & 0.17 \\
\hline 2 Nov & 156 & 38.4 & 1.5 & 0.02 & 83.9 & 3.2 & 0.09 \\
\hline Mean & 158 & 36.7 & 1.5 & 0.02 & 81.4 & 3.2 & 0.10 \\
\hline \multicolumn{8}{|c|}{ Waste water treatment plant } \\
\hline $14 \mathrm{Apr}$ & 3.45 & 7.1 & 1209 & 2.9 & 0.2 & 58.4 & 0.31 \\
\hline 8 May & 2.66 & 10.0 & 1159 & 4.8 & 0.3 & 43.1 & 0.51 \\
\hline $16 \mathrm{May}$ & 2.02 & 7.9 & 1360 & 8.7 & 0.2 & 38.5 & 0.93 \\
\hline 19 Jun & 2.50 & 6.4 & 1327 & 3.5 & 0.1 & 46.4 & 0.37 \\
\hline 27 Sep & 3.08 & 2.1 & 1529 & 3.6 & 0.1 & 65.9 & 0.38 \\
\hline 2 Nov & 3.52 & 7.1 & 1289 & 1.0 & 0.2 & 63.6 & 0.11 \\
\hline Mean & 2.87 & 6.8 & 1312 & 4.1 & 0.2 & 52.7 & 0.44 \\
\hline
\end{tabular}

total phosphorus is larger, ca 3 to 4 times the phosphate supply (P. Balmer pers. comm.).

\section{Nutrient fluxes, sources and sinks}

A simple budget model, based on conservation principles was used to calculate fluxes and internal sources and sinks for nutrients within the estuary. By assuming stationary conditions, the following equations for volume (mass) and salt balance are valid upstream of an arbitrary cross-section in the estuary (see Fig. 6):

$$
\begin{aligned}
& Q_{\mathrm{f}}=Q_{1}-Q_{0} \\
& Q_{1} S_{1}=Q_{0} S_{0}
\end{aligned}
$$

Here the fresh water supply $\left(Q_{1}\right)$ and the surface and deep water salinities, $S_{1}$ and $S_{0}$ respectively, are known quantities. Thus, the fluxes of surface and deep water $\left(Q_{1}\right.$ and $\left.Q_{0}\right)$ were calculated for each expedition and for each of the cross-sections at Stns 3,5 and 6. A similar conservation equation, where $P$ is the net nutrient source (production), was used for budgets of nitrate, ammonium and phosphate:

$$
Q_{f} C_{1}+Q_{w} C_{w}=Q_{1} C_{1}-Q_{0} C_{0}-P
$$

Here, $C_{l}, C_{1}$ and $C_{0}$ are the (known) concentrations in fresh water, surface and deep water, according to
Fig. 6. The waste water supply, $Q_{w} C_{w}$ (see above) is included for cases where the outlet is situated upstream of the cross-section for which $P$ is determined.

Net nutrient fluxes, including waste water and river supply, are shown separately for each expedition and for different cross-sections in Table 5. The corresponding mean fluxes, with a separation between surface and deep water, are shown in Fig. 7a to c. We can immediately see that deep water nutrient supply is an important term. For phosphate (Fig. 7c) the deep water supply is even larger than supply from waste water and river.

Fig. $7 \mathrm{a}, \mathrm{b}$ show us that there are large sinks for nitrate as well as for ammonium within the estuary.

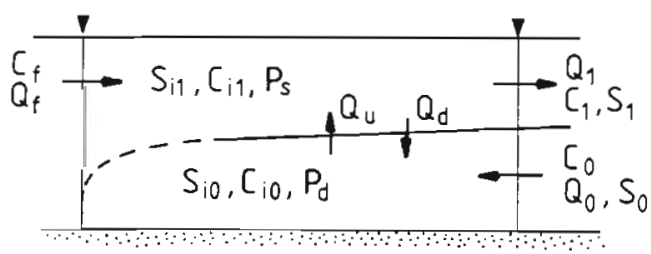

Fig. 6. Idealized 2-layer estuary circulation. $Q_{1}$ : fresh water supply; $C$ : concentration of an arbitrary compound, S: salinity; $Q_{u}, Q_{d}$ : up- and downward flux, respectively, of water through the halocline; $P_{\mathrm{d}}\left(P_{\mathrm{s}}\right)$ : net production in deep (surface) water of an arbitrary compound with concentration $C . P=$ $P_{\mathrm{d}}+P_{\mathrm{s}}$ 
Table 5. River and waste water supply. Net flux of nitrate, ammonium and phosphate $\left(\mathrm{mmol} \mathrm{s}^{-1}\right)$ calculated for cross-sections at Stns 3, 5 \& 6 (see Eqs. 1a, b \& c in text for definitions of variables) (-): Sampling was not dense enough to obtain reliable results for ammonium and phosphate at Stn 3, which is situated downstream of, and close to, the waste water outlet

\begin{tabular}{|c|c|c|c|c|c|c|c|c|}
\hline \multirow[t]{2}{*}{ Date } & \multirow[t]{2}{*}{$\begin{array}{l}\text { River supply, } \\
\qquad Q_{\mathrm{f}} C_{\mathrm{l}}\end{array}$} & \multirow[t]{2}{*}{$\begin{array}{l}\text { Waste water supply, } \\
\qquad Q_{w} C_{w}\end{array}$} & \multicolumn{3}{|c|}{$\begin{array}{c}\text { Net flux } \\
Q_{1} C_{1}-Q_{0} C_{0}\end{array}$} & \multicolumn{3}{|c|}{$\begin{array}{c}\text { Net source, } \\
P\end{array}$} \\
\hline & & & $\operatorname{Stn} 3$ & $\operatorname{Stn} 5$ & Stn 6 & $\operatorname{Stn} 3$ & $\operatorname{Stn} 5$ & $\operatorname{Stn} 6$ \\
\hline \multicolumn{9}{|c|}{ Nitrate } \\
\hline $14 \mathrm{Apr}$ & 6817 & 14 & 7200 & 7145 & 6391 & 369 & 334 & -440 \\
\hline 8 May & 6464 & 21 & 6485 & 2692 & 1827 & 0 & -3793 & -4685 \\
\hline $16 \mathrm{May}$ & 5490 & 14 & 5294 & 5705 & -1572 & -210 & 201 & -7076 \\
\hline 19 Jun & 5560 & 7 & 5947 & 5335 & 1512 & 380 & -232 & -4055 \\
\hline 27 Sep & 4556 & 7 & 4940 & 4497 & 4237 & 377 & -66 & -326 \\
\hline 2 Nov & 5990 & 14 & 6455 & 7054 & 8156 & 451 & 1050 & 2252 \\
\hline \multicolumn{9}{|c|}{ Ammonium } \\
\hline $14 \mathrm{Apr}$ & 408 & 4171 & - & 4728 & 2615 & - & 149 & -1964 \\
\hline 8 May & 120 & 3083 & - & -3 & -96 & - & 3206 & -3300 \\
\hline 16 May & 165 & 2742 & - & 2001 & -2540 & - & -906 & -5447 \\
\hline 19 Jun & 168 & 3317 & - & 2557 & 151 & - & -928 & -3334 \\
\hline 27 Sep & 294 & 4709 & - & 3010 & 1531 & - & -1993 & -3472 \\
\hline 2 Nov & 234 & 4537 & - & 5032 & 3858 & - & 261 & -913 \\
\hline \multicolumn{9}{|c|}{ Phosphate } \\
\hline $14 \mathrm{Apr}$ & 5 & 10 & - & 93 & 17 & - & 78 & 2 \\
\hline $8 \mathrm{May}$ & 0 & 16 & - & -107 & -55 & - & -123 & -71 \\
\hline $16 \mathrm{May}$ & 3 & 30 & - & 21 & 8 & - & -12 & -25 \\
\hline 19 Jun & 3 & 12 & - & 27 & 15 & - & 12 & 0 \\
\hline 27 Sep & 5 & 12 & - & -29 & -134 & - & -46 & -151 \\
\hline 2 Nov & 3 & 4 & - & 63 & 38 & - & 56 & 31 \\
\hline
\end{tabular}

The net nitrate sink upstream of Stn 6 amounts to 2600 mmol s${ }^{-1}$ compared to a total supply of $7300 \mathrm{mmol} \mathrm{s}^{-1}$. For ammonium there is a sink of ca $3200 \mathrm{mmol} \mathrm{s}^{-1}$, while the supply is $5500 \mathrm{mmol} \mathrm{s}^{-1}$. Table 5 indicates a seasonal variability. The sinks are largest during summer, while in November the estuary acts as a source for nitrate and phosphate.

More detailed information of which sources and sinks are involved can be obtained by using separate equations for surface and deep water. According to Fig. 6, the following equations are valid for the deep water upstream of an arbitrary cross-section:

$$
\begin{aligned}
& Q_{\mathrm{u}}=Q_{\mathrm{d}}+Q_{0} \\
& Q_{0} S_{0}+Q_{\mathrm{d}} S_{\mathrm{i} 1}=Q_{\mathrm{u}} S_{10}
\end{aligned}
$$

Here, $S_{\mathrm{i} 0}$ and $S_{11}$ are the horizontal mean salinities in deep and surface water between the cross-sections considered. From Eqs. 2a \& b the upward and downward flux of water through the halocline, $Q_{\mathrm{u}}$ and $Q_{\mathrm{d}}$ respectively, can be calculated. Thereafter $Q_{\mathrm{u}}$ and $Q_{\mathrm{d}}$ can be used to calculate the net nutrient source for the deep water, $P_{\mathrm{d}}$ (or for the surface water, $P_{\mathrm{s}}$ ), according to the equations:

$$
\begin{aligned}
& P_{\mathrm{d}}=Q_{0} C_{0}+Q_{\mathrm{d}} C_{\mathrm{i} 1}-Q_{\mathrm{u}} C_{10} \\
& P_{\mathrm{s}}=Q_{\mathrm{f}} C_{\mathrm{f}}-Q_{1} C_{1}+Q_{\mathrm{u}} C_{10}-Q_{\mathrm{d}} C_{\mathrm{i} 1}
\end{aligned}
$$

where $C_{\mathrm{i} 0}$ and $C_{\mathrm{i} 1}$ are the horizontal mean concentrations in deep and surface water.

There are too few data to calculate $P_{\mathrm{d}}$ and $P_{\mathrm{s}}$ separately for each expedition. However, the order of magnitude of $P_{\alpha}$ and $P_{\mathrm{s}}$ for the inner regions, between Stn 1 and $\operatorname{Stn} 3$, can be obtained by using yearly mean values of the quantities involved in Eqs. 2a to $c$ (see Table 6). By putting the mean values of Table 6 into Eq. 2c, we find that there is a (marginal) net source for nitrate of $28 \mathrm{mmol} \mathrm{s}^{-1}$ below the halocline. The corresponding net source for ammonium amounts to $88 \mathrm{mmol} \mathrm{s}^{-1}$. One way of interpreting this result is that mineralization in the deep water upstream of Stn 3 amounts to $116 \mathrm{mmol} \mathrm{s}^{-1}$. These numbers are still small compared to the sinks calculated for the whole estuary; however, these are confined to a limited area. More-

Table 6. Salinity and nitrogen concentrations used for calculating $P$ (source term) upstream of Stn 3 . See text for definitions of variables

\begin{tabular}{|lcc|}
\hline Salinity & Nitrate & Ammonium \\
\hline$S_{0}=21.74 \mathrm{psu}$ & $C_{0}=4.63 \mu \mathrm{mol}^{-1}$ & $C_{0}=3.02 \mu \mathrm{mol}^{-1}$ \\
$S_{\mathrm{i} 0}=20.96 \mathrm{psu}$ & $C_{10}=5.62 \mu \mathrm{mol}^{-1}$ & $C_{\mathrm{i0}}=3.55 \mu \mathrm{mol}^{-1}$ \\
$S_{\mathrm{i} 1}=3.78 \mathrm{psu}$ & $C_{\mathrm{i} 1}=31.30 \mu \mathrm{mol}^{-1}$ & $C_{\mathrm{i} 1}=2.61 \mu \mathrm{mol}^{-1}$ \\
\hline
\end{tabular}


over, as denitrification is likely to occur, gross mineralization can be much larger.

\section{Particulate organic material}

The mean particulate organic carbon, nitrogen and phosphorus concentrations ( $\mathrm{PC}, \mathrm{PN}, \mathrm{PP}$ ) in river water were $41,4.1$ and $0.3 \mu \mathrm{mol} \mathrm{l}^{-1}$, respectively, being similar to those of the reference station. The river water concentrations were surprisingly low with regard to the visibility (Secchi depth of about $1 \mathrm{~m}$, Selmer \& Rydberg 1992) and low compared to observations in the River Nissan further south on the west coast, where $\mathrm{PC}$ and $\mathrm{PN}$ could amount to 140 and $7 \mu \mathrm{mol} \mathrm{\textrm {I } ^ { - 1 }}$ respectively (Selmer 1988b). A weak decrease of both
PN and PC downstream is probably due to mixing from deep to surface water, while higher values of $\operatorname{Stn} 4$ may be due to waste water supply.

\section{Oxygen}

Oxygen was measured intermittantly at most stations. The surface water was always saturated or, at the outer stations, over-saturated by up to $30 \%$ (June 1989). The deep water never exhibited low saturation values. The lowest value, ca $70 \%$, was observed at Stn 1 in June 1989. This expedition deviated from the others, indicating significant production and consumption in surface and deep water, respectively. The net nutrient sink, however, was not extremely large (Table 5, see 'Discussion').
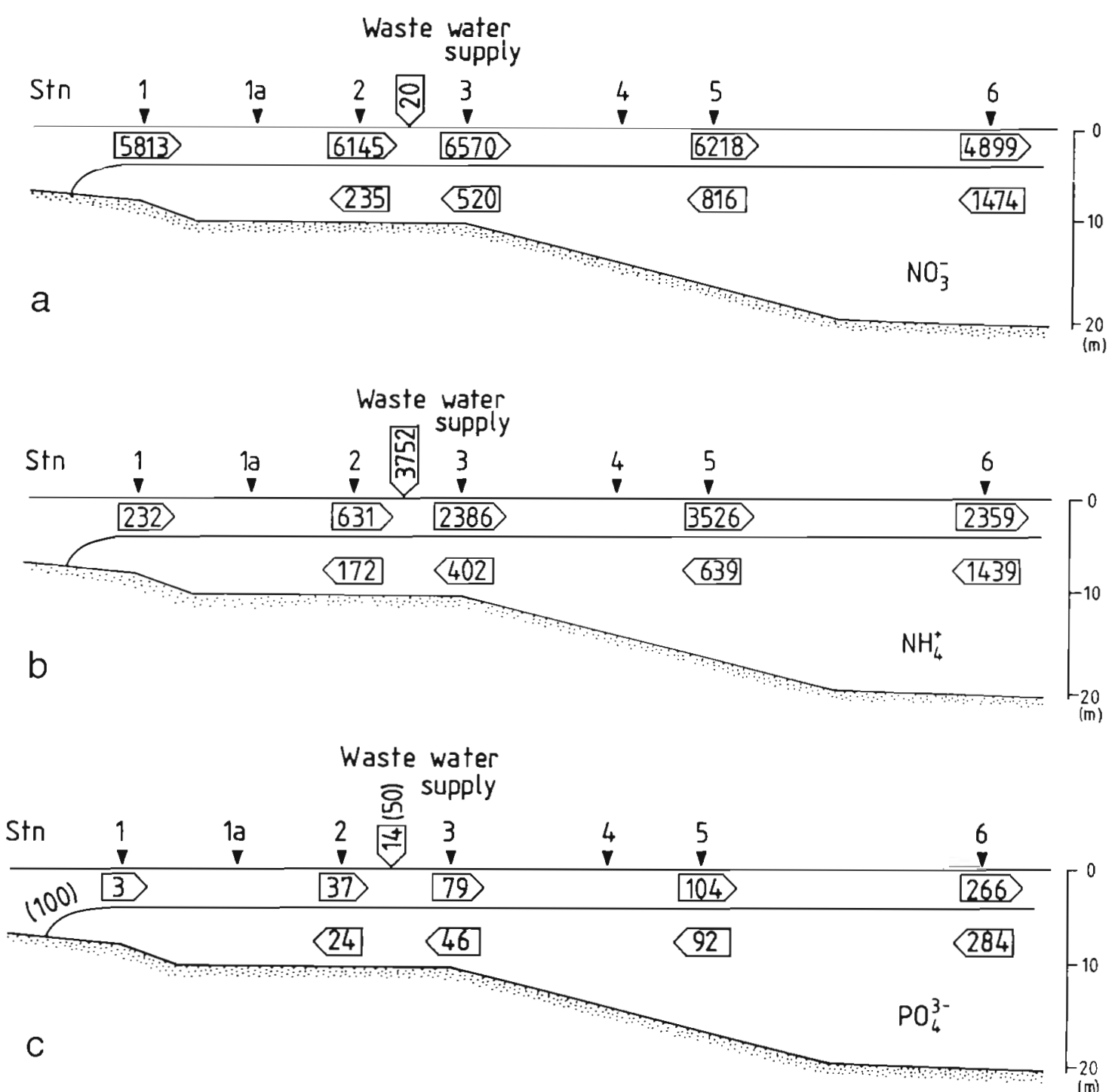

Fig. 7. Mean values of nutrient transport $\left(\mathrm{mmol} \mathrm{s}^{-1}\right)$ in the estuary based on 6 observations during 1989. (a) nitrate; (b) ammonium; and (c) phosphate 


\section{Chlorophyll a}

Chlorophyll a measurements were undertaken in May I (first expedition in May, see Table 1) and September 1989. The concentrations were low $k 2 \mathrm{mg}$ chl a $\mathrm{m}^{-3}$ ) except at Stn 6 when in September a Chaetoceros spp. bloom (see Selmer \& Rydberg 1992) caused values of $9 \mathrm{mg}$ chl a $\mathrm{m}^{-3}$. The concentrations were also higher at the reference station, 4.3 and $4.8 \mathrm{mg} \mathrm{chl} \mathrm{a} \mathrm{m}^{-3}$, respectively. These values are normal for Kattegat with a moderate primary production of ca $100 \mathrm{gC} \mathrm{m}^{-2} \mathrm{yr}^{-1}$ (Rydberg et al. 1990).

\section{Ammonium and nitrate uptake}

Measurements of ammonium and nitrate uptake in the surface layer (uppermost $2 \mathrm{~m}$ ) were made in July and October 1988 at Stns 1 to 4, and in May I and September 1989 at Stns 1 to 6 . The results are shown in Table 7 . At the inner stations, ammonium uptake was ca $30 \mathrm{nmol} \mathrm{l}^{-3} \mathrm{~h}^{-1}$. This enhancement was probably due to particle adsorption (Wukasch \& Moos 1984) which is a predominant factor in fresh water systems (Gardner et al. 1991). Uptake at the outer stations and at the reference station was between 20 and $100 \mathrm{nmol}$ $\mathrm{l}^{-1} \mathrm{~h}^{-1}$ (with a few exceptions). These values are somewhat higher than other results reported from the Swedish west coast, where the rate of ammonium uptake averages $20 \mathrm{nmol} \mathrm{l}^{-1} \mathrm{~h}^{-1}$ except for bloom periods (e.g. Sahlsten et al. 1988, Pettersson 1991). The ammonium uptake was extremely high at Stn 4 in May 1989 ( $\left.639 \mathrm{nmol} \mathrm{l}^{-1} \mathrm{~h}^{-1}\right)$, coinciding with a Skeletonema costatum population in an obvious state of growth (K. Pettersson pers. comm.). The high ammonium uptake rate at Stn 4 in July 1988 (of ca $100 \mathrm{nmol} \mathrm{l}^{-1} \mathrm{~h}^{-1}$ ) coincided with a Prorocentrum micans bloom (Selmer \& Rydberg 1992). In September, the uptake rates were low in the river water out to Stn 5 , while at Stn 6 and

Table 7. Uptake rates $\left(\mathrm{nmol}^{-1} \mathrm{~h}^{-1}\right)$ of nitrate and ammonium in the River Göta älv estuary

\begin{tabular}{|lrrrrrrr|}
\hline & \multicolumn{7}{c|}{ Stations } \\
\cline { 2 - 7 } & 1 & 2 & 3 & 4 & 5 & 6 & Ref \\
\hline Nitrate & & & & & & & \\
25 Jul 1988 & 9 & 7 & 6 & 8 & - & - & 30 \\
17 Oct 1988 & 8 & 5 & 3 & 3 & - & - & 3 \\
8 May 1989 & - & 2 & 2 & 3 & 3 & 15 & 32 \\
27 Sep 1989 & - & 3 & 4 & 4 & 3 & 11 & 15 \\
Ammonium & & & & & & & \\
25 Jul 1988 & 52 & 33 & 27 & 105 & - & - & 112 \\
17 Oct 1988 & 20 & 8 & 8 & 9 & - & - & 18 \\
8 May 1989 & - & 20 & 20 & 639 & 18 & 16 & 49 \\
27 Sep 1989 & - & 24 & 26 & 29 & 19 & 61 & 78 \\
\hline
\end{tabular}

the reference station the uptake was high, 60 to 80 nmol $l^{-1} \mathrm{~h}^{-1}$. Measurements in October 1988 indicated low ammonium uptake at all stations, which is in accordance with late season and low phytoplankton concentrations (Selmer \& Rydberg 1992).

Nitrate uptake was usually less than $10 \mathrm{nmol}^{-1} \mathrm{~h}^{-1}$, except at the reference station and at $\operatorname{Stn} 6$, where the

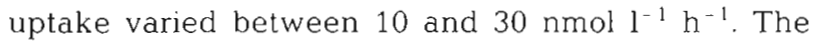
measurements at the reference station, however, indicated nitrate uptake typical for Kattegat (Sahlsten et al. 1988). In general, the uptake rates of ammonium were 2 to 5 times higher than the uptake of nitrate, both in the low saline surface water and at the reference station. This is in accordance with the normally observed preference for ammonium over nitrate (e.g. McCarthy et al. 1977).

\section{Mineralization and denitrification}

Nitrogen mineralization rate was measured in surface water in July 1988 . The rates increased from 40 to $100 \mathrm{nmol} \mathrm{l}^{-1} \mathrm{~h}^{-1}$ at the inner stations, to $200 \mathrm{nmol} \mathrm{l}^{-1}$ $\mathrm{h}^{-1}$ at Stn 4 and $400 \mathrm{nmol} \mathrm{l}^{-1} \mathrm{~h}^{-1}$ at the Kattegat reference station. These rates were high compared to earlier measurements in Swedish coastal waters, ranging from 10 to $100 \mathrm{nmol} \mathrm{l}^{-1} \mathrm{~h}^{-1}$ (Selmer 1988b), and also compared to results from other estuaries (e.g. Glibert 1982, Hanson et al. 1990).

Denitrification was studied in May II (second expedition in May, see Table 1) 1989. No increases in $\mathrm{N}_{2} \mathrm{O}$ concentrations during the incubations as compared to the in situ concentrations were observed. However, all sampling depths exhibited good oxygen saturation, eliminating an expectancy of significant denitrification. This result, however, does not exclude denitrification near the sediment surface or in the sediments, where the oxygen concentrations are expected to be low.

\section{DISCUSSION}

\section{External nutrient supply}

The external supply of inorganic nitrogen to the estuary was dominated by the river transport which, in turn was dominated by nitrate. During our measurements the river transport amounted to nearly $6000 \mathrm{mmol} \mathrm{s}^{-1}$ or 2700 ton $\mathrm{yr}^{-1}$ (Fig. 7a, b). The waste water supply amounted to $3800 \mathrm{mmol} \mathrm{s}^{-1}$ (1700 ton $\mathrm{y}^{-1}$ ), being dominated by ammonium. Import of nitrogen from the Kattegat, here determined as deep water nitrogen supply entering through a cross-section at Stn 6, added $2900 \mathrm{mmol} \mathrm{s}^{-1}$. A summary is given in Table 8. 
Table 8. Average external nutrient supply to the estuary of River Göta älv ( $\mathrm{mmol} \mathrm{s}^{-1}$ )

\begin{tabular}{lrrrrr|} 
& $\mathrm{NO}_{3}{ }^{-}$ & $\mathrm{NH}_{4}{ }^{+}$ & Org. N & $\mathrm{PO}_{4}{ }^{3-}$ & Org. P \\
\hline River supply & 5800 & 200 & $<3000$ & 3 & 100 \\
Waste water supply & 20 & 3800 & 300 & 14 & 50 \\
Deep water supply & 1400 & 1400 & - & 200 & - \\
\hline
\end{tabular}

These results were obtained from measurements taken during the period from March to November 1989, which is the period with significant primary production in Swedish west-coast waters (Rydberg et al. 1990). Thus, as there were no winter measurements, the results should be regarded as averages for the productive season. For the supply terms, however, the seasonal variations are probably moderate; the discharge of fresh water is nearly constant throughout the year, with river nitrate concentrations being no more than $10 \%$ lower during summer as compared to winter (according to the Swedish Environmental Protection Agency's observations downstream of Lake Vänern). Waste water nitrogen supply also decreases somewhat during summer due to a combination of lower discharge and ammonium concentrations. Seasonal variations in the deep water nitrogen supply, however, are larger as the deep water normally originates from Kattegat surface water, which is usually nutrientdepleted from April to October but relatively rich in nitrate ( 5 to $10 \mu \mathrm{mol}$ DIN $1^{-1}$ ) during winter. During our study, however, the mean deep water DIN concentrations at Stn 6 were in the order of $4 \mu \mathrm{mol} \mathrm{l}^{-1}$ (Fig. 2b, c), indicating that this estimate may also correspond to a typical yearly mean value. Thus we may conclude that our results concerning the magnitude of the different inorganic nitrogen supply terms are also representative on a yearly basis as well, with the exception being the internal production term $P$.

There is, however, in addition to the external supply of inorganic nitrogen, also an external supply of organic nitrogen both through the river transport and through the waste water supply, which by mineralization in the estuary implies an additive (internal) source for inorganic nitrogen. Mineralization may very well be important in the estuary since phosphate and ammonium concentrations increase upstream in the deep water (compare Fig. 2 c, d). According to the measurements by the Swedish Environmental Protection Agency, organic nitrogen compounds amount to $35 \%$ of the total nitrogen transport in the river, indicating an organic nitrogen supply of ca $3000 \mathrm{mmol} \mathrm{s}^{-1}$. It is unlikely, however, that more than a limited part of this supply is mineralized within the estuary and even if a contribution from waste water is added $\left(300 \mathrm{mmol} \mathrm{s}^{-1}\right.$; P. Balmer pers comm.), this combined external/inter- nal nitrogen supply is small compared to the other supply terms.

The external supply of phosphate, which is dominated by the deep water supply, is surprisingly small (Fig. $7 \mathrm{c}$ ), amounting to ca $300 \mathrm{mmol} \mathrm{s}^{-1}$. The inorganic $\mathrm{N}: \mathrm{P}$ supply ratio amounts to ca 42 (atomic); if the deep water supply is excluded, the corresponding ratio is 600. The nutrient concentrations upstream of Stn 6 (Fig. 2b to d) clearly mirrors the dissimilarity in loading: where low or zero phosphate concentrations indicate a phytoplankton production which is phosphate limited.

\section{Internal sources and sinks}

Through the nutrient flux calculations based on Eqs. 1 \& 2, we concluded that there were large sinks for nitrate $\left(2600 \mathrm{mmol} \mathrm{s}^{-1}\right)$ and for ammonium $(3200 \mathrm{mmol}$ $\mathrm{s}^{-1}$ ) in the outer part of the estuary, causing almost $50 \%$ of the external nitrogen supply to disappear inside Stn 6. During summer these figures are even higher (Table 5). For phosphate the corresponding sink is $35 \mathrm{mmol} \mathrm{s}^{-1}$ according to Fig. $7 \mathrm{c}$, but is probably larger due to a more rapid decomposition of organic phosphorus than of nitrogen. Considering the Redfield ratio, this is still very small compared to the inorganic nitrogen sinks.

One natural explanation for the large nitrogen sink would be an extensive denitrification in or near the bottom, where heavy shipping traffic and continuous dredging cause abnormal conditions which could enhance sediment processes. This explanation was also supported by the low oxygen concentrations in June and August 1989. When measured directly in the water, however, denitrification was not detectable (May II 1989). Nitrification was also low on this occasion (a maximum of ca $30 \mathrm{nmol} \mathrm{I}^{-1} \mathrm{~d}^{-1}$ in deep water, $\mathrm{V}$ Enoksson pers. comm.).

To be able to explain the nitrogen sink by denitrification, the inorganic nutrients within the surface water must be transported to the bottom of the estuary, which normally occurs by uptake due to primary production and a consecutive sedimentation of plankton. Direct measurements of nitrate and ammonium uptake using ${ }^{15} \mathrm{~N}$ incubations, on the other hand, indicate that the 
uptake is far too small compared to the nitrogen sinks. The mean uptake of nitrate amounted to 10 to $20 \mathrm{nmol}$ $\mathrm{l}^{-1} \mathrm{~h}^{-1}$ and the mean uptake of ammonium to $60 \mathrm{nmol}$ $\mathrm{l}^{-1} \mathrm{~h}^{-1}$, disregarding the extreme value in May 1989 (Table 7). These mean values, although based on just 4 different occasions, correspond fairly well with typical uptake rates in the Kattegat (Sahlsten et al. 1988), even if the ammonium uptake was somewhat higher. However, if these mean values are integrated over the estuarine surface area $\left(50 \mathrm{~km}^{2}\right)$ and depth $(2 \mathrm{~m}$ of surface water) inside $\operatorname{Stn} 6$, we find uptake figures of 250 to $500 \mathrm{mmol} \mathrm{s}^{-1}$ and $1500 \mathrm{mmol} \mathrm{s}^{-1}$ respectively, which is approximately 20 and $50 \%$, respectively, of the indirectly calculated average nitrogen sinks (even less if we take into account the seasonal variability in the sink terms; see Table 5).

The mean oxygen concentrations showed a slight under-saturation in the deep water inwards and oversaturation in the surface water outwards, a tendency most prominently observed in June 1989. Including the exchange with the deep water but not with the atmosphere, the increased oxygen concentrations on this occasion corresponded to an oxygen production of $18100 \mathrm{mmol} \mathrm{O}_{2} \mathrm{~s}^{-1}$ which, according to the Redfield ratio (138:16), would imply a nitrogen assimilation of $2100 \mathrm{mmol} \mathrm{s}^{-1}$. This is however, 3 to 4 times lower than the net nitrogen sink in June 1989 (7500 mmol DIN s$~^{-1}$, Table 5). In conclusion, the direct uptake by phytoplankton and subsequent sedimentation seems too small to be responsible for the sink

A factor that may be of importance in estuaries is intracellular storage of nitrogenous nutrients. This ability has been found among diatoms and dinoflagellates (Raven 1980), populations which are typical for the Göta älv estuary (Selmer \& Rydberg 1992). Intracellular storage of nitrate was also found by Pettersson (1989) in the estuary of the River Nissan further south on the Swedish west coast, and in the Skagerrak (Pettersson 1991). Intracellular storage of ammonium could also be possible, but we would then expect increasing concentrations of PN but not of PP in the outer part of the estuary. This is also the case at Stn 6 (Selmer \& Rydberg 1992). The concentrations are 1 to 2 $\mu \mathrm{mol} \mathrm{l}^{-1}$ higher at this station than at the inner stations. On the other hand, to be of significance compared to the calculated nitrogen sink, the increase in PN should be in the order of $10 \mu \mathrm{mol} \mathrm{l}^{-1}$, as seen from the nitratesalinity diagram of Fig. 4. The actual nitrate concentration in the surface water at Stn 6 is $4 \mu \mathrm{mol} \mathrm{l}^{-1}$ instead of $8 \mu \mathrm{mol} \mathrm{l}^{-1}$ according to the mixing line. This difference is an alternative expression for the nitrate sink which amounts to $40 \%$ of the total nitrogen sink. Thus, an increase in PN on the order of $1 \mu \mathrm{mol} \mathrm{l^{-1 }}$ is too small to make intracellular storage a major reason for the nitrogen $\sin k$.

\section{Concluding remarks}

Since neither nitrogen uptake, intracellular storage of nitrogen nor denitrification can explain the calculated nitrogen sinks, it is reasonable to ask whether there is an inaccuracy in the measurements. It appears that there are too few direct rate measurements and that we need to cover different seasons more efficiently. We may also question whether, given enough measurements and allowing for the volumes and areas chosen as representative, the indirect calculations are indeed correct. We may refer here to the calculation technique, where salinity has been used as an independent variable up to the stage of drawing figures. Thus, estimates on nutrient fluxes, sinks and sources are exact if referring to salinity (e.g. the flow of deep water at $\operatorname{Stn} 6$ is determined as the flow with a mean deep water salinity observed at Stn 6 . In fact, this mean salinity appears at many positions and many depths within the estuary). One source of error may be the volumes and areas chosen to make a comparison between direct and indirect measurements possible. However as long as the difference in results between the 2 methods approaches 1 order of magnitude, the absolute volumes can not be a major source of error.

This is also true for the problem of estimating the discharge $Q_{\mathrm{t}}$, which is influenced by local winds and sea level variations. In fact, $Q_{1}$ should be representative for a couple of days which is the typical water residence time. Neither our measurements nor the Electricity Board's estimates are quite reliable. On the other hand, all results are dependent on $Q_{r}$ in a similar fashion, and thus an error of maybe $20 \%$ is still not a serious drawback. At Stn 6, there were differences in concentrations between the northern and the southern station which were not explainable solely as salinity variations. We noted that the coriolis force hampered diffusion of the plume, and that limited diffusion of the waste water resulted in an uncontrolled sink (the measured concentrations of ammonium are higher than motivated by the measured supply). Looking at the fluxes passing Stn 5, however, we can see that we have the major part of the waste water flow under control. We are also aware of the problems with automated nutrient analysis in an estuary with large differences in sample salinity. However, we believe that we have taken the effects of salinity into account.

In spite of the problems discussed above, we regard the very large sinks as real, and that there is an ongoing process withdrawing inorganic nitrogen from the surface water (to the sediments where denitrification can occur). We do not believe that local denitrification in particles within the water is to a large extent possible. This process may be coupled to the very strong salinity gradients of this estuary, possibly pro- 
voking direct binding of ammonium and perhaps also nitrate to particles (although the latter has never been described and is theoretically unlikely), with a subsequent sedimentation of particles out of the surface water. However, we hope to continue with further studies on uptake rates based on ${ }^{15} \mathrm{~N}$ measurements and/or ${ }^{14} \mathrm{C}$ measurements, intensified oxygen measurements (for indirect calculations of uptake and denitrification rates) and denitrification studies on sediments. Measurements will also be extended to cover the winter period.

Acknowledgements. We thank Anna Bagger-Sjöbäck and Birgitta Odén for qualified technical assistance; Ulf Johansson and Michael Wrangstadh for acting as skippers; Lars-Åke Gisselsson, Lena Janzén, Sue van Ness and Helen Nilsson for help on board during the expeditions; Ann Mattsson for providing data from the waste water treatment plant; Karin Pettersson for the phytoplankton counts and valuable discussions on these; Agneta Malm for drawing the tigures; Maureen Jehler for language correction; and 3 anonymous reviewers for valuable comments. This work was supported by the Swedish Environmental Protection Agency, Göteborgsregionens Ryaverksaktiebolag and Oskar och Lili Lamms Stiftelse.

\section{LITERATURE CITED}

Armstrong, F. A. J., Sterns, C. R., Strickland, J. D. H. (1967). The measurement of upwelling and subsequent biological processes by means of the Technicon Autoanalyzer associated equipment. Deep Sea Res. 14: $381-389$

Blackburn, T H. (1979). Method for measuring rates of $\mathrm{NH}_{4}{ }^{+}$ turnover in anoxic marine sediments, using a ${ }^{15} \mathrm{~N}_{-} \mathrm{NH}_{4}{ }^{+}$ dilution technique. Appl. environ. Microbiol. 37: 760 - 765

Brattberg, G. (1986). Decreased phosphorus loading changes phytoplankton composition and biomass in the Stockholm archipelago. Vatten 42: 141-153

Caperon, J., Schell, D., Hirota, J., Laws, E. (1979). Ammonium excretion rates in Kaneohe Bay. Hawaii, measured by a ${ }^{15} \mathrm{~N}$ isotope dilution technique. Mar. Biol. 54:33-40

Carlberg, S. R. (1972). New Baltic Manual. Cooperative Research Report of International Council for the Exploration of the Sea, Copenhagen, p. 9-72

Dugdale, R. C., Wilkerson, F. P. (1986). The use of ${ }^{15} \mathrm{~N}$ to measure nitrogen uptake in eutrophic oceans; experimental considerations. Limnol. Oceanogr. 31:673-689

Elmgren, R. (1988). Eutrofieringsstudier i Himmerfjärden 1976-1985. Report no. 3537, Swedish Environmental Protection Agency, Stockholm

Fiedler, R., Proksch, G. (1975). The determination of nitrogen15 by emission and mass spectrometry in biochemical analysis: a review. Anal. Chim. Acta 78: 1-62

Gardner, W. S., Seitzinger, S. P., Malczyk, J. M. (1991). The effects of sea salts on the forms of nitrogen released from estuarine and freshwater sediments: does ion pairing affect ammonium flux? Estuaries 14: 157-166

Glibert, P. M. (1982). Regional studies of daily, seasonal and size fraction variability in ammonium remineralization. Mar. Biol. 70: 209-222
Graneli, E., Graneli, W., Rydberg, L. (1986). Nutrient limitation at the ecosystem and the phytoplankton community level in the Laholm Bay, south-east Kattegat. Ophelia 26: 181-194

Graneli, E., Wallström, K., Larsson, U., Graneli, W., Elmgren, R. (1990) Nutrient limitation of primary production in the Baltic Sea area. Ambio 19: 142-151

Hanson, R. B., Robertson, C. Y., Yoder, J. A., Verity, P. G., Bishop, S. S. (1990). Nitrogen recycling in coastal waters of southeastern US during summer 1986. J. mar. Res. 48: $641-660$

Koroleff, F. (1976). Determination of phosphorus. In: Grasshoff, K. (ed.) Methods of seawater analysis. Verlag Chemie, New York, p. 117-126

Kristiansen, S., Paasche, E. (1982). Preparation of ${ }^{15} \mathrm{~N}$ labelied phytoplankton samples for optical emission spectrometry, Limnol. Oceanogr. 27: 373-375

Larsson, U., Elmgren, R., Wulff, F. (1985). Eutrophication and the Baltic Sea: causes and consequences. Ambio 14: 9-14

McCarthy, J. J., Taylor, W. R., Taft, J. L. (1977). Nitrogenous nutrition of the plankton in Chesapeake Bay. I. Nutrient availability and plankton preferences. Limnol. Oceanogr. 22: $996-1001$

Pettersson, K. (1989). Nitrogen uptake and its role in marine phytoplankton population dynamics. Ph.D. thesis, University of Göteborg

Pettersson, K. (1991). Seasonal uptake of carbon and nitrogen and intracellular storagge of nitrate in planktonic organisms in Skagerrak. J. exp. mar. Biol. Ecol. 151: 121-137

Raven, J. A. (1980). Nutrient transport in microalgae. In: Rose, A. H., Morris, J. G. (eds.) Advances in microbial physiology. Academic Press, London, p. 47-266

Redfield, A. C., Ketchum, B. H., Richards, F. A. (1963). The influence of organisms on the composition of sea-water. In: Hill, M. N. (ed.) The sea, vol. 2. Wiley, New York, p. 26-77

Rosenberg, R., Elmgren, R., Fleischer, S., Jonsson, P., Persson, G., Dahlin, H. (1990). Marine eutrophication case studies in Sweden. Ambio 19: 102-108

Rydberg, L. (1986). Some observations of nutrient fluxes through the coastal zone. Rapp. P.-v. Reun. Cons. int. Explor. Mer 186: 49-59

Rydberg, L., Edler, L., Floderus, S., Graneli, W. (1990). Interaction between supply of nutrients, primary production, sedimentation and oxygen consumption in SE Kattegatt. Ambio 19: 134-141

Sahlsten, E., Sörensson, F., Pettersson, K. (1988). Planktonic nitrogen uptake in the south-eastern Kattegat. J. exp. mar. Biol. Ecol. 121: 227-246

Selmer, J.-S. (1988a). Ammonium regeneration in the marine environment. Ph.D. thesis, University of Göteborg

Selmer, J.-S. (1988b). Ammonium regeneration in eutrophicated coastal waters of Sweden. Mar. Ecol. Prog. Ser. 44: $265-273$

Selmer, J-S., Rydberg, L. (1992). Hydrographical and hydrochemical measurements and phytoplankton counts in the estuary of River Göta älv, Sweden, 1988-1990. Report no 16, Department of Oceanography, University of Göteborg, Sweden

Selmer, J.-S., Sörensson, F. (1986). New procedure for the extraction of ammonium from natural waters for ${ }^{1} \mathrm{~N}$ isotope ratio determination. Appl environ. Microbiol. 52: 577-579

Söderström, J. (1986). Kustvattnet i Göteborgsregionen 1982-84. Länsstyrelsen i Göteborgs och Bohus Län, Publikation 1986: 5

Solorzano, L. (1969). Determination of ammonium in natural waters by the phenolhypochlorite method. Limnol. Oceanogr 14: 799-801 
Sorensen, J. (1979). Denitrification rates in a marine sediment as measured by the acetylene inhibition technique. Appl. environ. Microbiol. 36: 139-143

Strickland, J. D. H., Parsons, T R. (1968). A practical handbook of seawater analysis. Pigment analysis. Bull. Fish. Res. Bd Can. 167: 185-206

This artucle was submitted to the editor
Valderrama, J (1981). The simultaneous analysis of total nitrogen and total phosphorus in natural waters. Mar. Chem. 10: 109-122

Wukasch, R. F., Moos, L. P. (1984). Sorption of ammonia nitrogen on river borne suspended solids. Wat. Sci. Tech. 17: $713-718$

Manuscript first received: February 13, 1992

Revised version accepted: November 12, 1992 